\title{
Route Selection to Minimize Helicopter Disturbance of Molting Pacific Black Brant: A Simulation
}

\author{
MARK W. MILLER ${ }^{1,2}$
}

(Received 23 December 1993; accepted in revised form 21 June 1994)

\begin{abstract}
I used a previously described simulation model to assess the effects of helicopter activity on approximately 18000 molting Pacific black brant (Branta bernicla nigricans) near Teshekpuk Lake, Alaska. Bell 206 and Bell 412 helicopters were simulated flying across the molting grounds along six flight lines at various altitudes and frequencies between two airfields. The model determined the behavioral and energetic responses of every bird encountered by the aircraft during an overflight, then calculated the weight of these birds at the end of wing molt. Body condition of the brant, reflected in weight loss, was used to quantify the impact of helicopter disturbance. The number of birds in each of five risk categories was determined for each route, altitude, helicopter type, and overflight frequency. Flight lines and overflight patterns that minimized disturbance to the molting population were identified. Slightly altering the direct route between the two airfields resulted in up to $91 \%$ fewer birds experiencing heavy weight loss. Flying either helicopter type around the southern edge of the molting grounds caused the least disturbance; flying parallel to the coast, $1.6 \mathrm{~km}$ inland, caused the most. The Bell 412 caused up to $15 \%$ more weight loss than did the smaller helicopter. Weight loss along a given flight line can be reduced by 1 ) flying at altitudes greater than $1065 \mathrm{~m}$ altitude, 2) flying only when most brant are in their second week of molt, 3) minimizing flight frequency, and 4) avoiding use of the larger Bell 412 when possible.
\end{abstract}

Key words: brant, human disturbance, aircraft, Arctic Coastal Plain, simulation model, feather molt

RÉSUMÉ. On s'est servi d'un modèle de simulation décrit précédemment pour évaluer les répercussions de l'activité liée à l'utilisation d'un hélicoptère sur environ 18000 bernaches noires (Branta bernicla nigricans) en période de mue près de Teshekpuk Lake en Alaska. On a simulé le vol d'hélicoptères Bell 206 et Bell 412 au-dessus des zones de mue le long de six trajectoires de vol à différentes altitudes et fréquences entre deux terrains d'aviation. Le modèle a déterminé les réactions comportementales et énergétiques de chaque oiseau rencontré par l'appareil durant un survol, puis a calculé le poids de ces oiseaux à la fin de la mue des ailes. On a utilisé l'état du corps de la bernache, reflété par la perte de poids, afin de quantifier les effets des perturbations causées par l'hélicoptère. Dans chacune des cinq catégories à risque, on a déterminé le nombre d'oiseaux pour chaque route, altitude, type d'hélicoptère et fréquence de survol. On a identifié les trajectoires de vol et les schémas de survol qui minimisaient les perturbations pour la population en période de mue. Une légère modification au trajet direct entre les deux terrains d'aviation a eu pour résultat que $91 \mathrm{p}$. cent moins d'oiseaux ont subi une importante perte de poids. Le survol de l'un ou l'autre des types d'hélicoptère dans la périphérie méridionale des aires de mue a produit le moins de perturbation; le survol parallèle à la côte, à 1,6 km à l'intérieur des terres en a causé le plus. Le Bell 412 a provoqué jusqu'à 15 p. cent de plus de perte de poids que l'hélicoptère plus petit. On peut réduire la perte de poids le long d'un trajet de vol donné en 1) volant à plus de $1065 \mathrm{~m}$ d'altitude, 2) en ne volant que lorsque la plupart des bernaches sont dans leur deuxième semaine de mue, 3) en minimisant la fréquence des vols et 4) en évitant d'utiliser le plus gros hélicoptère Bell 412 lorsque c'est possible.

Mots clés: bernache cravant, perturbation humaine, aéronef, plaine côtière arctique, modèle de simulation, mue des plumes

Traduit pour la revue Arctic par Nésida Loyer.

\section{INTRODUCTION}

Human disturbance of waterfowl has long been recorded in the literature; however, only recently have the effects of such encounters on distribution and behavior been documented (Dahlgren and Korschgen, 1992). Geese often respond adversely to people, boats, hunting activity, low-flying aircraft (Owens, 1977; Kramer et al., 1979; Bélanger and Bédard, 1989; Ward et al., 1994), loud noises (Owens, 1977), and automobile traffic (Madsen, 1985; Bélanger and Bédard, 1989). Aircraft, especially helicopters (Owens, 1977), seem to cause the most severe response (Bélanger and Bédard, 1989). Aircraft have disturbed brant on their wintering grounds (Kramer et al., 1979), staging areas (Ward et al., 1994), nesting sites (Eisenhauer, 1977), and molting grounds (Derksen et al., 1979). Wariness varies among species (Burger, 1981; Madsen, 1985; Mosbech and Glahder, 1991), and brant are considered extremely vulnerable to human disturbance (Einarsen, 1965; Smith and Jensen, 1970; Jensen, 1990; Ward et al., 1994). Indeed, human disturbance might be the reason that black brant have largely abandoned former wintering grounds on the west coast of California and Oregon in favor of Mexico (Einarsen, 1965; Smith and Jensen, 1970).

Helicopters frequently are employed by businesses operating

\footnotetext{
${ }^{1}$ Department of Wildlife and Fisheries Sciences, Texas A\&M University, College Station, Texas 77843, U.S.A.

${ }^{2}$ Present address: Department of Zoology, University of Guelph, Guelph, Ontario N1G 2W1, Canada

(C) The Arctic Institute of North America.
} 
in Arctic Alaska to transport personnel and cargo. They are more versatile in landing at unimproved sites, carry a larger load than fixed-wing aircraft of similar size, and cause less damage to the tundra than ground vehicles. D.V. Derksen (National Biological Survey, Anchorage, pers. comm., 1991) first noted displacement of molting brant from a coastal plain lake due to aircraft activity in 1979. Owens (1977) reported that loud noises such as gunshots flushed wintering dark-bellied brent geese $(B . b$. bernicla). $\mathrm{He}$ noted that the birds quickly became habituated to most sounds, but were very slow to do so with aircraft, and never habituated to small low-flying aircraft.

Molt is an energetically costly process (Paine, 1972; King, 1974; Ankney, 1979), and many waterfowl species, including brant in Arctic Alaska, lose weight during wing molt (Taylor, 1993). Meeting the nutrient requirements of wing molt might not cause a decline in the body condition of undisturbed waterfowl (Ankney 1979, 1984; Pehrsson, 1987; Taylor, 1993); but the addition of stress from aircraft overflights on molting brant in Arctic Alaska might inhibit the birds' ability to complete their molt while maintaining or acquiring a body condition adequate for subsequent migration to staging areas (Taylor, 1993).

As oil exploration and development in the Arctic expands, the magnitude of helicopter impact on the molting brant population will depend on the location of future work sites (Penfold and Buoy, 1986), the intensity of aircraft traffic in these immediate areas, and the routes and altitudes used to fly into and out of these sites. The objectives of this paper were to use a spatially explicit computer model (Miller et al., 1994) to 1) simulate disturbance of a molting Pacific black brant population resulting from aircraft traffic along various flight lines, 2) relate repeated helicopter disturbance to body condition of individual birds in the model, and 3) adjust altitude and pattern of helicopter traffic to reduce disturbance along individual flight lines.

\section{STUDY AREA}

Pacific black brant molt primarily on the Arctic Coastal Plain between Teshekpuk Lake and Cape Halkett, approximately $130 \mathrm{~km}$ southeast of Barrow and $180 \mathrm{~km}$ northwest of Prudhoe Bay (Fig. 1). This area extends inland from the Arctic Ocean about $30 \mathrm{~km}$, and encompasses about $2000 \mathrm{~km}^{2}$ (Derksen et al., 1979). The molting ground is characterized by tundra vegetation (Spetzman, 1959; Wiggins and Thomas, 1962; Hultén, 1968) underlain with continuous permafrost (Wahrhaftig, 1965; Péwé, 1975).

Over 200 large thaw lakes (Black and Barksdale, 1949) are found within the molting grounds. Of these, about 45 lakes are used by brant each year during their four-week summer wing molt. Although the number of brant on individual lakes can vary markedly across years, and the same 45 lakes are not necessarily used each year (Miller et al., 1994), the general distribution of brant on the molting grounds is roughly constant. Weller et al. (in press) found that the number of molting brant on eight large thaw lakes was correlated highly with their major feeding habitat, moss flats, along lake shores.

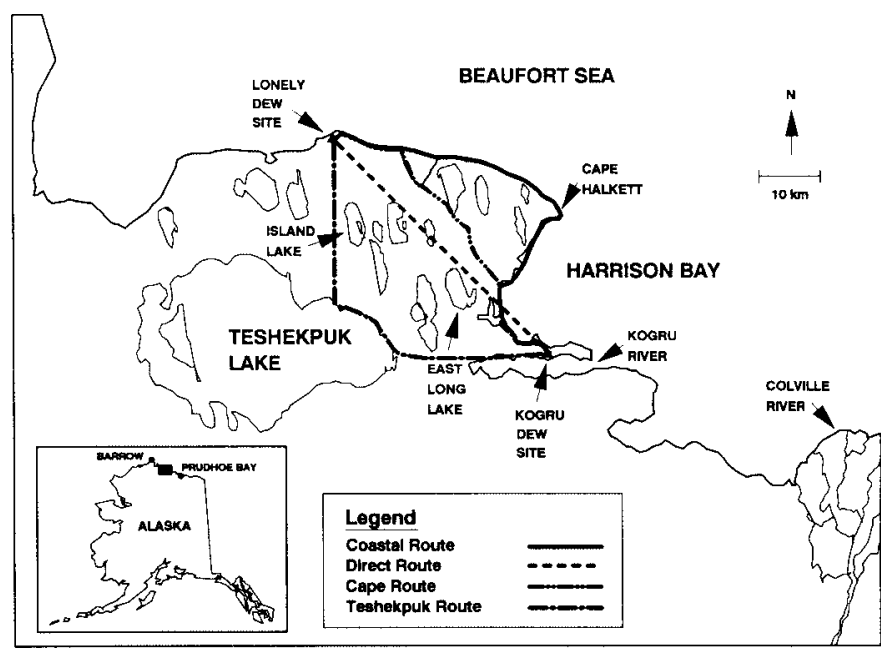

FIG. 1. The molting grounds and simulated flight lines on the North Slope of Alaska between Cape Halkett and Teshekpuk Lake. The Coastal-Inland and Coastal-Seaward Routes are slight variations of the Coastal Route and are not shown (map after Jensen, 1990).

\section{OVERVIEW OF THE PROBLEM}

Up to $23 \%$ of the total Pacific black brant population molts each year in the study area (King and Hodges, 1979). Although a few brant breed locally (Derksen et al., 1982), most of the molters are failed breeders or immature birds (King, 1970; Taylor, 1993), which arrive on the molting grounds near the end of June and stay approximately four weeks (Derksen et al., 1979). Brant cannot fly for most of the time required to replace flight feathers (Bellrose, 1980; Taylor, 1993), and they spend most of their flightless period on discrete moss flats along the shores of partially drained lakes (Derksen et al., 1979, 1982; Jensen, 1990). Upon completion of molt, the birds move first to the Beaufort Sea coast (Jensen, 1990) and then to a premigration staging area on the Alaska Peninsula (Derksen et al., 1982; Ward et al., 1994). All brant do not begin molting simultaneously, and a few birds are present on the molting grounds until mid-August (Derksen et al., 1979; Taylor, 1993).

Jensen (1990) determined the effects of helicopter disturbance on molting brant by conducting experimental overflights at East Long Lake (Fig. 1). As an aircraft first approaches a flock, the birds become alert. If the aircraft continues to approach, the geese might walk, then run, and eventually seek safety by entering a lake (Jensen, 1990). Several variables influence how brant react to an aircraft. These variables, flock size, aircraft type, and aircraft proximity, have been examined in detail elsewhere (Jensen, 1990; Miller et al., 1994).

\section{MODEL DESIGN AND DATA}

\section{The Conceptual Model}

The disturbance model consists of two submodels, a Flight Line (FL) submodel and a Behavior andEnergetics (BE) submodel (Fig. 2). A detailed description of the model and its assumptions is available in Miller (1991) and Miller et al. (1994). 
The FL submodel includes a $1.6 \mathrm{~km}^{2}$ grid over the entire molting grounds. Brant are assigned to grid cells on the basis of flock locations and average flock sizes recorded during aerial surveys. In total, the submodel contains a fixed distribution of 18118 brant (Miller et al., 1994). However, the distribution of birds in the model can be updated if future aerial surveys detect a marked shift in lake usage on the molting grounds.

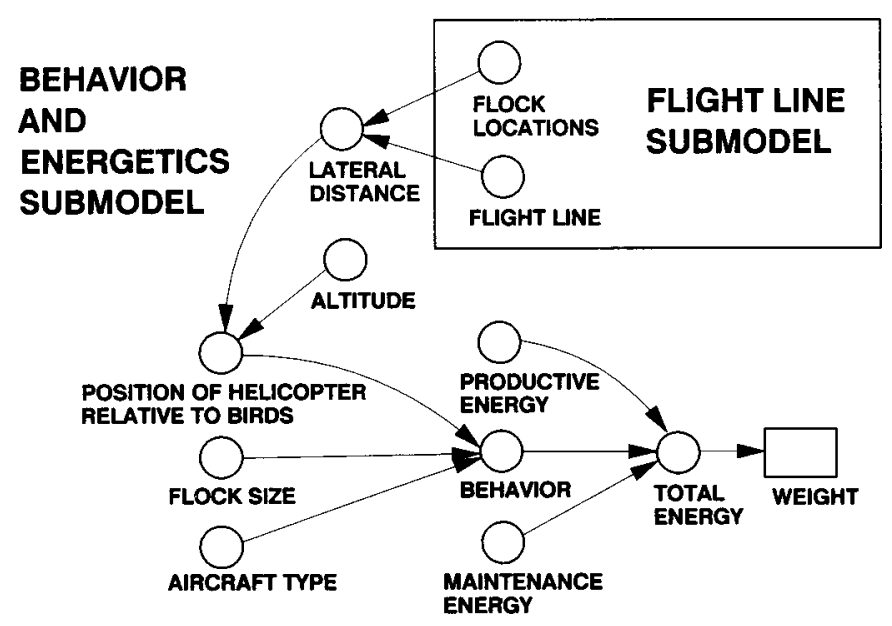

FIG. 2. The conceptual disturbance model.

The FL submodel can simulate either a Bell 206 or the larger Bell 412 helicopter flying over the molting grounds along any route while recording the number, size, and general location of flocks along that flight line. The model records all brant within a $3.3 \mathrm{~km}$ radius of the aircraft (measured along the ground), approximately $95-100 \%$ of all flocks from $>3.3-3.5 \mathrm{~km}$ away, $90-100 \%$ of all flocks $>3.5-4.0 \mathrm{~km}$ distant, and $80 \%$ of all flocks from $>4.0-5.0 \mathrm{~km}$ away. Although the model might fail to detect some brant $>3.3-5.0 \mathrm{~km}$ distant, the behavioral response of such birds to the aircraft is almost invariably minimal (Jensen, 1990). All birds recorded by the FL submodel are considered "encountered," and represent the total number of birds along that flight line.

The BE submodel determines the reaction of each encountered flock to the aircraft on the basis of overflight altitude, lateral distance (shortest distance between the aircraft and the birds, perpendicular to the line of flight), aircraft type and flock size. Not all birds recorded as "encountered" are necessarily disturbed by the aircraft. For example, if the helicopter is flying at a high altitude, an encountered flock might not react adversely, whereas that same encountered flock might be disturbed if overflight altitude were lower. Field data generated by experimental overflights were incorporated into the model to simulate the response of brant to Bell 206 overflights. Unfortunately, the number of Bell 412 experimental overflights was too limited for this approach. Therefore an algorithm was constructed to convert Bell 206 field data to hypothetical Bell 412 data (Miller et al., 1994).

The BE submodel determines the amount of energy that birds expend in response to overflights during molt. First, the daily energy budget for brant is calculated by estimating the amount of energy that birds ingest while foraging; then, that energy is allocated to major expenditures (Taylor, 1993; Miller et al., 1994). Birds gain weight if the daily energy budget is positive; if it is negative, they lose weight. Helicopter disturbance causes weight loss by 1) initiating energetically expensive disturbance behaviors, and 2) reducing foraging time available to the birds. The model was written using the software package STELLA (Richmond et al., 1987) and a Macintosh II $^{\mathrm{TM}}$ microcomputer.

\section{The Data Base}

I used 10 years of U.S. Fish and Wildlife Service aerial survey data to determine lake usage by molting brant and average flock size per lake. Most surveys were flown at the peak of molt in midJuly. Experimental overflights also were conducted in mid-July; 140 flights from 1987 to 1989 used a Bell 206; 21 in 1988 used a Bell 412 (Jensen, 1990).

Jensen and Adair (1988) constructed a bioenergetics simulation model to assess the weight loss of a molting brant resulting from standard helicopter overflights of various frequencies (a standard helicopter overflight equals a Bell 206 flying at $305 \mathrm{~m}$ directly over one adult male brant at one lake). Taylor (1993) greatly developed and elaborated that model through an extensive review of the literature on avian physiology. Miller et al. (1994) connected flight-line and behavior submodels to Taylor's (1993) bioenergetics model. Data on body weight of brant at various stages of molt were collected by Taylor (1993).

\section{SIMULATION OF AIRCRAFT DISTURBANCE}

\section{Flight-Line Submodel: \\ Simulating Brant-Helicopter Encounters}

Only two landing strips, Lonely and Kogru Distant Early Warning (DEW) Line sites, are present in the molting area. I simulated six flight lines between the two airfields to examine impacts of alternative routes on body weight of molting brant (Fig. 1). Two routes (Direct and Cape) pass over the Cape Halkett region, that portion of the molting grounds most densely populated by brant. The Direct Route is the shortest flight line between the two airfields. The Cape Route, a modified version of the Direct Route, was designed to minimize the number of flocks and birds encountered while flying over Cape Halkett. Three flight lines parallel the coast, which may serve as a landmark for flying in poor weather: the Coastal Route follows the coast, the Coastal-Seaward Route parallels the coast $1.6 \mathrm{~km}$ at sea, and the Coastal-Inland Route follows the coast $1.6 \mathrm{~km}$ inland. The Teshekpuk Route extends south from Lonely to the north shore of Teshekpuk Lake, then eastward along the Kogru River to the Kogru DEW site.

The numbers of flocks and birds encountered along each route are summarized in Table 1. The Teshekpuk and CoastalSeaward Routes minimize the number of brant encountered by skirting the edge of the Cape Halkett region. The Direct, Cape, Coastal and Coastal-Inland Routes, which do not avoid the Cape, encounter 1402-6147 more birds than the first two routes. 
Of the six flight lines simulated, the Coastal-Inland Route encounters the most flocks $(67,42 \%$ of all brant flocks on the molting grounds) and the most birds (9587, 53\% of all brant in the area) while the Teshekpuk Route encounters the fewest flocks $(21,13 \%)$ and birds $(576,3 \%)$.

TABLE 1 . The number of flocks and birds encountered along flight lines between Lonely and Kogru airfields.

\begin{tabular}{lcc}
\hline \hline Flight line & Flocks & Birds \\
\hline Direct & 59 & 8284 \\
Cape & 48 & 4842 \\
Teshekpuk & 21 & 576 \\
Coastal & 49 & 6190 \\
Coastal-Seaward & 31 & 3440 \\
Coastal-Inland & 67 & 9587 \\
\hline \hline
\end{tabular}

\section{Simulating Behavior and Energetic Effects}

Each route was simulated at 11 altitudes using 10 and 50 overflights/day with both Bell 206 and Bell 412 helicopters. A quantity of ten flights/day (five trips to and from a work site) was chosen to represent daily low-level helicopter traffic associated with long-term business activity, while that of 50 flights/day represents the hypothetical maximum aircraft traffic, perhaps related to construction of a work site. Neither flight-frequency level was routinely observed on the molting grounds, perhaps because oil-related activity was not present during the study. For each simulation, I summarized the number of flocks and birds in each of five weightloss categories (Table 2). The magnitude of disturbance along a flight line varied with aircraft type, altitude, and overflight frequency.

TABLE 2. Classification system used to summarize model results.

\begin{tabular}{lcc}
\hline \hline Category & $\begin{array}{c}\text { Final weight of } \\
\text { individual brant } \\
(\mathrm{kg})\end{array}$ & $\begin{array}{c}\text { Weight loss of } \\
\text { individual brant } \\
(\mathrm{kg})\end{array}$ \\
\hline Not Disturbed & 1.27 & 0 \\
No Loss & 1.27 & 0 \\
Light Loss & $1.26-1.15$ & $0.01-0.12$ \\
Moderate Loss & $1.14-1.00$ & $0.13-0.27$ \\
Heavy Loss & $<1.00$ & $>0.27$ \\
\hline \hline
\end{tabular}

\section{Effect of Altitude}

Altitude strongly influenced helicopter impact on both the number of birds disturbed and their final weight (Fig. 3). At lower altitudes, the Bell 412 caused greater weight loss than did the Bell 206, but rarely increased the number of birds disturbed relative to the smaller helicopter. However, at higher altitudes, the Bell 412 typically increased both the number of birds disturbed and their weight loss. Flights $>1220$ m with a Bell 206 or at $1830 \mathrm{~m}$ with a Bell 412 caused practically no weight loss along any route. Overflights $<915 \mathrm{~m}$ altitude with a Bell 206 and $<1065$ m with a Bell 412 disturbed most birds along all routes. Generally, the degree of disturbance was inversely proportional to overflight altitude. However, the most weight loss along a given flight line occurred at 305 or $460 \mathrm{~m}$, rather than at $150 \mathrm{~m}$, regardless of aircraft type or overflight frequency.

10 BELL 206 OVERFLIGHTS/DAY

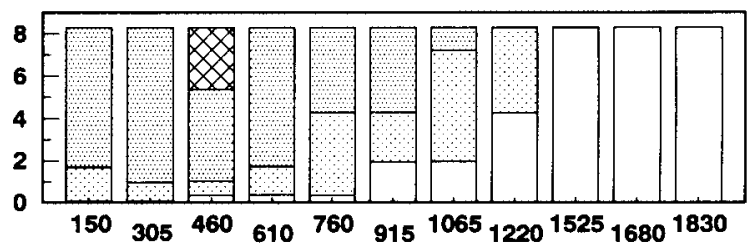

50 BELL 206 OVERFLIGHTS/DAY

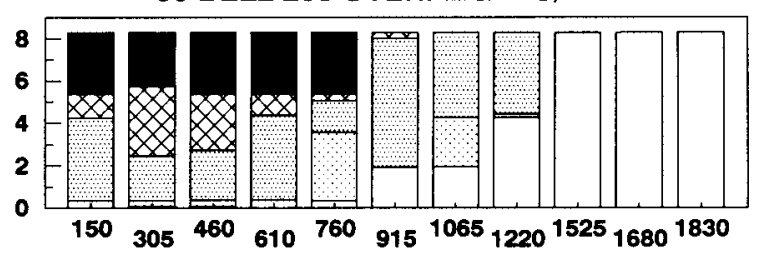

10 BELL 412 OVERFLIGHTS/DAY

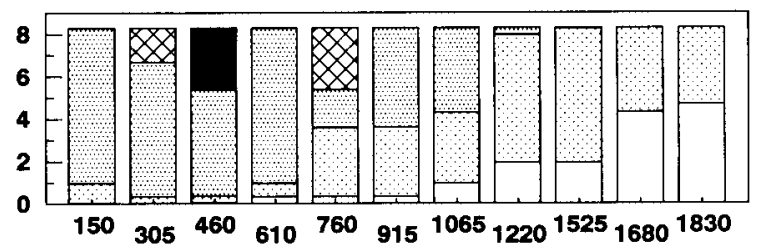

50 BELL 412 OVERFLIGHTS/DAY

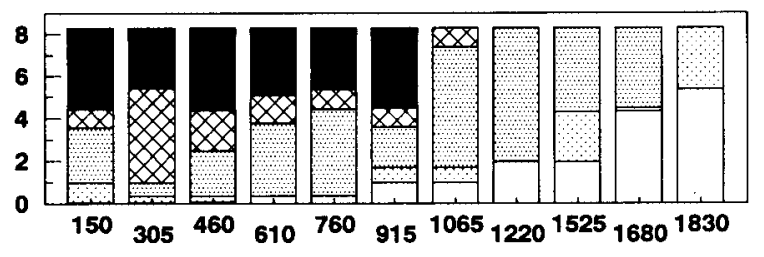

\section{ALTITUDE (m)}

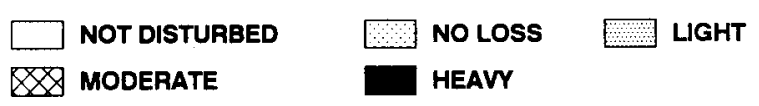

FIG. 3. Weight loss of brant subjected to 10 and 50 Bell 206 and Bell 412 overflights/day along the Direct Route at 11 different altitudes.

\section{Effect of Helicopter Type}

Because of the major impact that helicopters at $460 \mathrm{~m}$ had on the birds, and the tendency of aircraft in this area to fly at approximately $305-460 \mathrm{~m}$, I selected a $460-\mathrm{m}$ altitude to compare the effects of helicopter type. For both helicopter types, I calculated the average final weight of all brant that were disturbed by daily flights along each route. Depending on flight frequency, the Bell 412 caused 3-15\% more weight loss than did the smaller helicopter (Table 3). 
TABLE 3. Difference in average final weight of disturbed brant (Bell 206 vs 412, altitude $=460 \mathrm{~m}$ ).

\begin{tabular}{|c|c|c|c|c|c|c|}
\hline Route & $\begin{array}{c}\text { Bell } 206 \\
10 \mathrm{f} / \mathrm{d}^{1} \\
(\mathrm{~kg})\end{array}$ & $\begin{array}{c}\text { Bell } 412 \\
10 \mathrm{f} / \mathrm{d} \\
(\mathrm{kg})\end{array}$ & $\begin{array}{c}\text { Weight } \\
\text { difference } \\
(\%) \\
412 / 206\end{array}$ & $\begin{array}{c}\text { Bell } 206 \\
50 \mathrm{f} / \mathrm{d} \\
(\mathrm{kg})\end{array}$ & $\begin{array}{c}\text { Bell } 412 \\
50 \mathrm{f} / \mathrm{d} \\
(\mathrm{kg})\end{array}$ & $\begin{array}{c}\text { Weight } \\
\text { difference } \\
(\%) \\
412 / 206\end{array}$ \\
\hline Direct & 1.17 & 1.11 & +5 & 0.97 & 0.69 & +28 \\
\hline Cape & 1.24 & 1.22 & +2 & 1.17 & 1.07 & +8 \\
\hline Coastal & 1.21 & 1.18 & +3 & 1.07 & 0.90 & +16 \\
\hline Coast-Inland & 1.20 & 1.15 & +4 & 1.03 & 0.82 & +20 \\
\hline Coast-Seaward & 1.24 & 1.24 & +1 & 1.16 & 1.06 & +8 \\
\hline Teshekpuk & 1.25 & 1.22 & +2 & 1.20 & 1.10 & +8 \\
\hline \multicolumn{2}{|c|}{ Average for all routes } & & +3 & & & +15 \\
\hline
\end{tabular}

${ }^{1}$ flights/day

\section{Effect of Flight Lines/Routes}

I also selected a 460-m altitude to display direct comparisons of flight lines (Fig. 4). The Direct, Coastal, and Coastal-Inland Routes caused much more disturbance to the molting population than did the other three flight lines, regardless of aircraft type and overflight frequency. Flying the Direct Route generally caused the same impact as the Coastal-Inland Route, more than the Coastal Route, and much more than the Cape Route. Overflight altitude affected which flight line caused the least disturbance: the Teshekpuk Route caused the least disturbance at altitudes $<1220 \mathrm{~m}$ and the Coastal-Seaward Route at higher altitudes.

Although no mortality/weight associations are known for brant, I suspect that birds weighing $<1.00 \mathrm{~kg}$ at the end of molt are most likely to suffer decreased survival (Haramis et al., 1986). No birds lost large amounts of weight in response to 10 Bell 206overflights/day (Table4). With 10Bell412 overflights/ day, heavy weight loss occurred only at 460-m altitude. Fifty flights/day by either helicopter at low-to-mid altitudes resulted in large numbers of brant suffering heavy weight loss, except

TABLE 4. Mean ${ }^{1}$ number of brant experiencing heavy weight loss with standard deviation in parenthesis.

\begin{tabular}{ccccccccc}
\hline \hline \multirow{2}{*}{$\begin{array}{c}\text { Helicopter Flights } \\
\text { type }\end{array}$} & $\begin{array}{c}\text { Helicopter } \\
\text { per day }\end{array}$ & altitude (m) & $\mathrm{DI}^{2}$ & $\mathrm{CA}^{2}$ & $\mathrm{CO}^{2}$ & $\mathrm{CI}^{2}$ & $\mathrm{CS}^{2}$ & $\mathrm{TK}^{2}$ \\
\hline Bell 206 & 10 & All & 0 & 0 & 0 & 0 & 0 & 0 \\
Bell 412 & 10 & 460 & 2929 & 251 & 977 & 2150 & 0 & 0 \\
Bell 412 & 10 & All others & 0 & 0 & 0 & 0 & 0 & 0 \\
Bell 206 & 50 & $<915$ & 2854 & 567 & 1089 & 2531 & 479 & 45 \\
& & & $(167)$ & $(706)$ & $(250)$ & $(852)$ & $(1074)$ & $(100)$ \\
Bell 206 & 50 & $915-1830$ & 0 & 0 & 0 & 0 & 0 & 0 \\
Bell 412 & 50 & $<1065$ & 3442 & 744 & 1652 & 3256 & 558 & 151 \\
Bell 412 & 50 & $1065-1830$ & 0 & 0 & 0 & 0 & 0 & 0 \\
\hline \hline
\end{tabular}

${ }^{1}$ Each helicopter-type/flight-frequency combination was simulated 11 times for each route: once each for 11 different altitudes. For each helicopter-type/flight-frequency combination, simulation results were grouped by altitude as listed in the table. Means and standard deviations were calculated for each group.

${ }^{2} \mathrm{DI}=$ Direct, $\mathrm{CA}=$ Cape, $\mathrm{CO}=$ Coastal, $\mathrm{CI}=$ Coastal - Inland, $\mathrm{CS}=$ Coastal-Seaward, $\mathrm{TK}=$ Teshekpuk

along the Teshekpuk Route. Heavy weight loss did not occur along any flight line from overflights at high altitudes.

10 BELL 206 OVERFLIGHTS/DAY
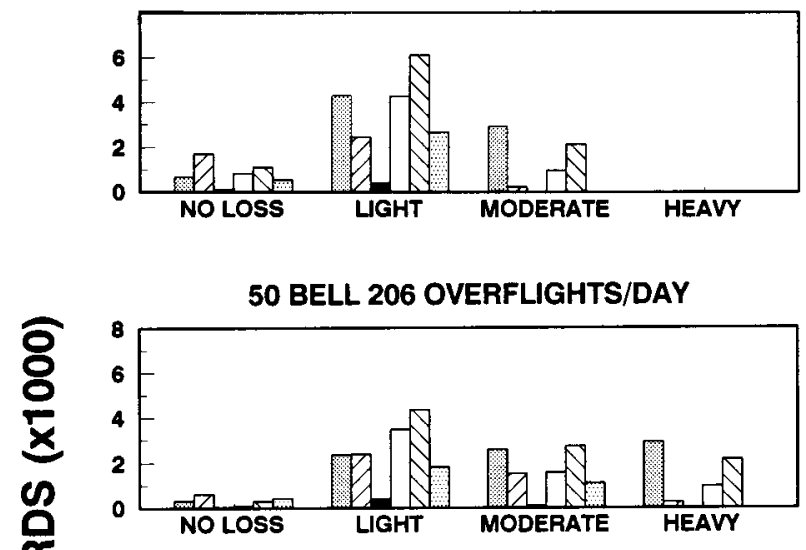

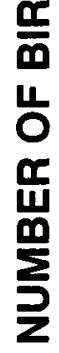
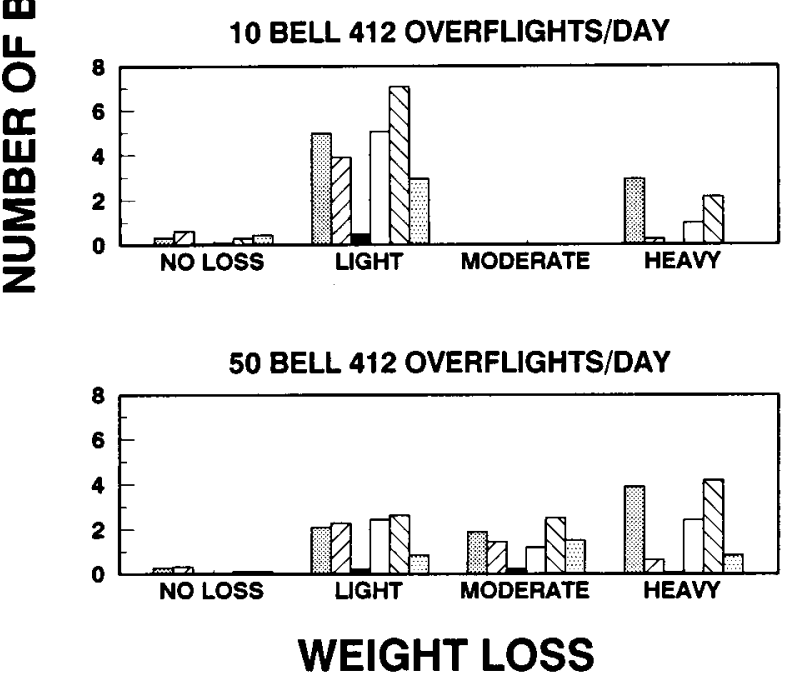

DIRECT COASTAL $\triangle 1$ COASTAL-INLAND

TESHEKPUK COASTAL-SEAWARD

FIG. 4. Weight loss of brant subjected to 10 and 50 overflights/day at 460-m altitude along six flight lines.

\section{Effect of Number of Overflights}

The number of overflights/day at 460-m altitude along the Direct Route was increased gradually (from 5 to 10, 20, 30, 40 and 50) to examine in greater resolution how the magnitude of aircraft activity affected birds (Fig. 5). Increasing overflight frequency usually caused greater impact on the brant, either by increasing the number of birds in the moderate and heavy weight-loss categories or by lowering the average weight of birds in these categories. This was particularly evident with the larger Bell 412. With the Bell 206, the number of birds experiencing moderate weight loss increased as overflights increased from 20 to 50/day and the average weight of birds in the heavy weight-loss category decreased. Heavy weight loss first occurred with 20 Bell 206 and 10 Bell 412 overflights/day. 


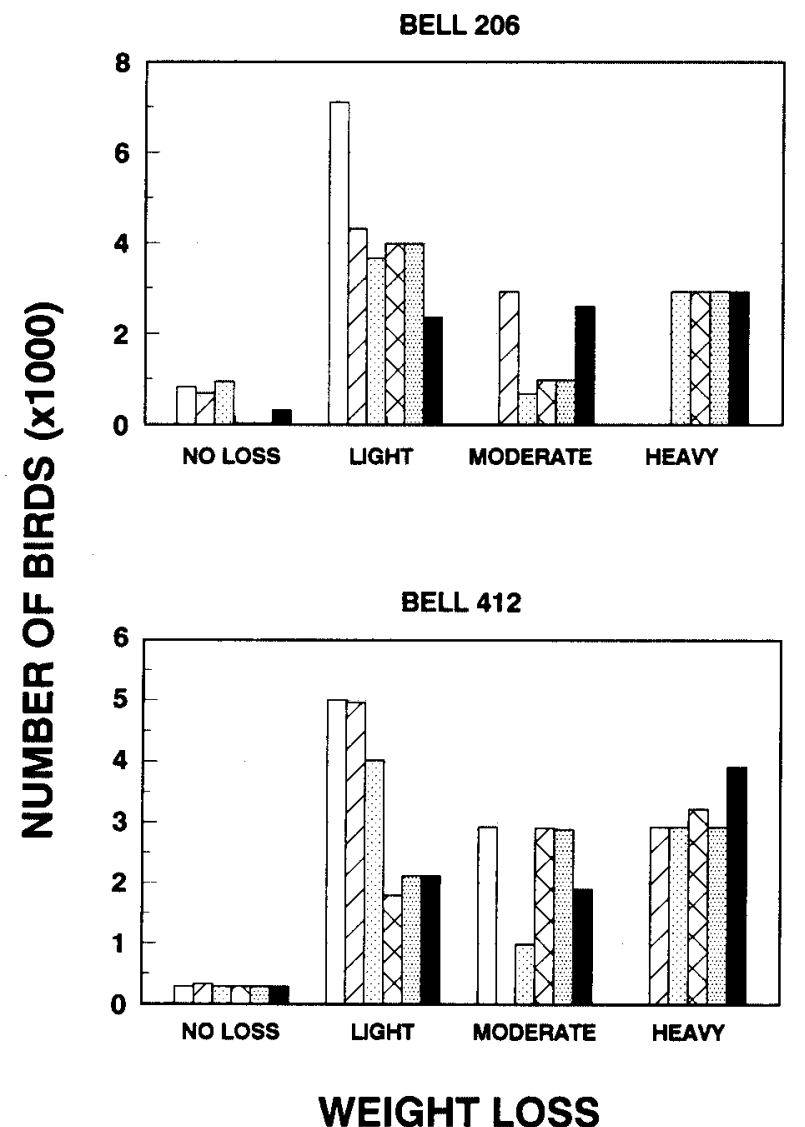

\section{OVERFLUGTS}

30 OVERFLGHTS

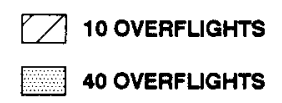

20 OVERFLIGHTS 50 OVERFLIGHTS

FIG. 5. Effect of increasing overflight frequency at 460-m altitude along the Direct Route.

Because of the magnitude of disturbance generated by the Bell 412, the pattern of overflights along the Direct Route was varied to determine whether the impact could be reduced. Results for a Bell 412 flying 19-20 flights/day vs 60 flights every third day were not significantly different (t-test, $p<0.05$ ) (Fig. 6). I also simulated 2-week periods of 50 Bell 412 flights/day beginning on Day 1, Day 8 and Day 15 of the 4-week molt period. The impact of disturbance during the first half of the molt period was lower than during the middle, and much less than during the second half (Fig. 7).

\section{MODEL VALIDATION}

Because of the relatively few experimental Bell 206 overflights (140) compared to the total possible variable combinations in the model ( 11 altitudes $\times 13$ lateral distance categories $\times 3$ flock sizes $=429$ ), all available data were incorporated into the model (Miller et al., 1994). Unfortunately, this left no data for validation of behavioral responses of brant to overflights at East Long Lake. Validation of predicted weight loss in response to repeated overflights along a given flight line is possible, but collection of the required data would be enormously expensive. Adaptive resource management, in which management policies are established and monitored experimentally (Lancia et al., 1993), might be the only method of testing these predictions (Conroy, 1993).

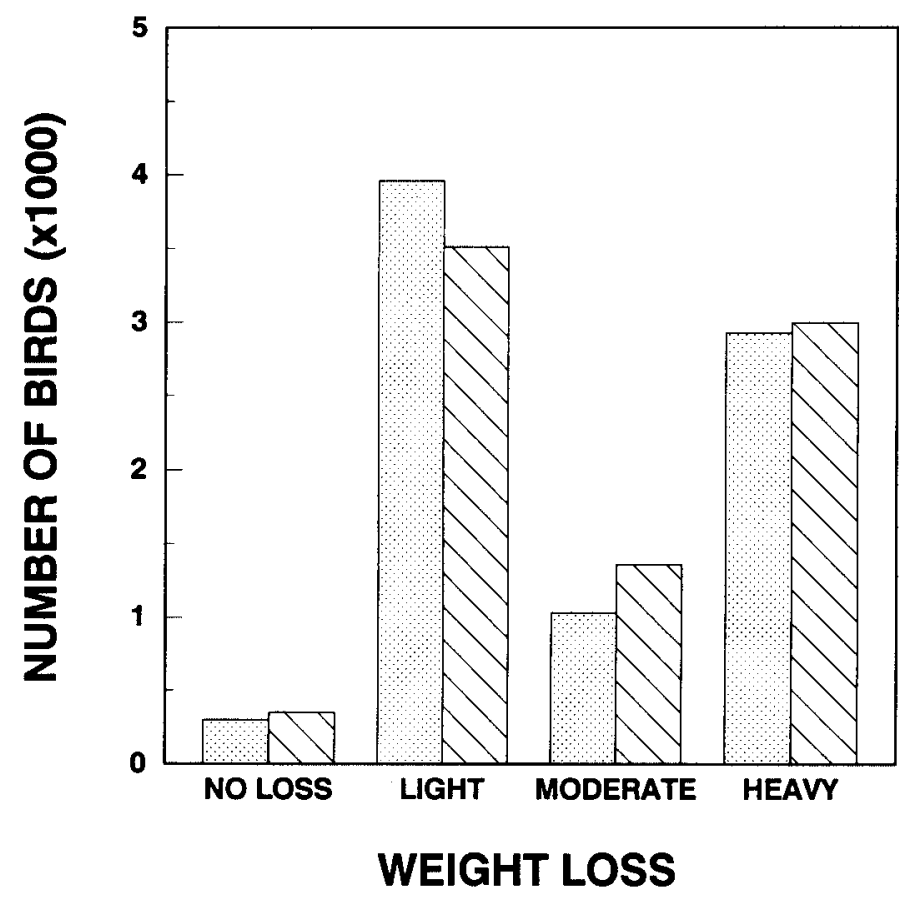

19-20 OVERFLIGHTS 60 OVERFLIGHTS

FIG. 6. Comparison of 19-20 Bell 412 overflights/day vs. 60 Bell 412 overflights every third day along the Direct Route at $460-\mathrm{m}$ altitude. Graph shows averages from 10 simulations. No significant difference was detected (t-test, $p<0.05$ ).

\section{DISCUSSION}

Weight loss, the only measure of risk currently available, was used to quantify the impact of helicopter disturbance on molting brant. A threshold value for weight below which brant might experience significantly lower survival has not been established. Pehrsson (1987) suggested that some weight loss during wing molt may be natural, making it easier for birds to fly before flight feathers are fully replaced. However, Taylor (1993) found that brant nearing completion of wing molt possessed lipid reserves equivalent to only $2-4 \%$ of body weight. He described these birds as "nutritionally emaciated" (Taylor, 1993:101). For brant already in such poor condition, the additional loss of $>21 \%$ of average normal body weight might result in abnormal or incomplete molt (Taylor, 1993), if not decreased survival.

Helicopter disturbance could begin even before brant start molting. When brant arrive on the molting grounds, birds capable of flight may desert a lake if disturbed by aircraft (E. Taylor, Texas A\&M University, College Station, Tx, pers. comm., 1989). Other lakes nearby might be suitable for molting. However, if undisturbed brant followed an ideal free distribution (Fretwell, 1972), they would maximize their fitness by selecting the best molting sites first. Fitness for the birds would be lower at alternative moss flats on either the same lake or a different one. 


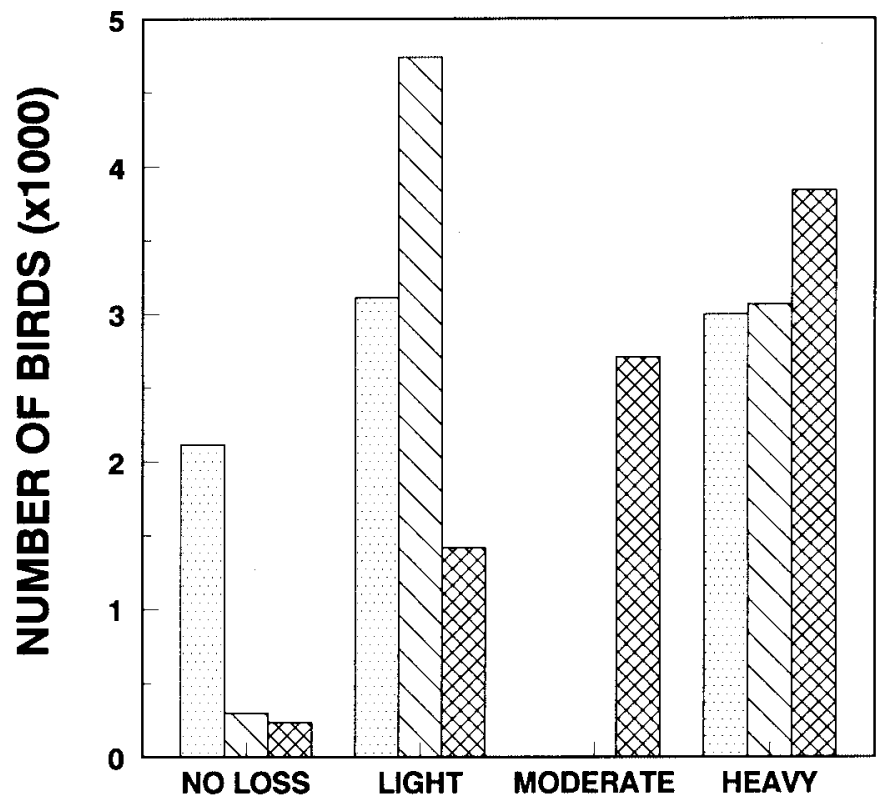

\section{WEIGHT LOSS}

\section{WEEK 1 \& 2}

\section{$\triangle$ WEEK 2 \& 3}

WEEK 3 \& 4

FIG. 7. Two-week pulses of 50 Bell 412 overflights/day along the Direct Route at 460-m altitude. Graph shows averages from 10 simulations.

It follows that intense helicopter activity could result in lower fitness for disturbed brant regardless of whether they abandoned their first choice of a molting site. Either the birds could stay at their original site and experience decreased body condition reacting to aircraft activity, or they could abandon their first site in favor of a poorer-quality, albeit undisturbed, molting area.

Once brant are flightless, avoidance of aircraft might be difficult or impossible. Theoretically, flightless brant subjected to such heavy harassment might 1) habituate, 2) compensate for lost feeding time, 3) swim to another less disturbed moss flat on the same lake, 4) swim along creeks to other less disturbed lakes, or 5) walk to another less disturbed lake. Jensen (1990) found that molting brant did not habituate to overflights. He also suggested that gut capacity, passage rates, and forage digestibility might limit the ability of brant to compensate for lost feeding time. On large lakes, and perhaps on lakes connected via streams, flightless brant might be able to swim to a less disturbed area. The former has been observed, but only rarely (Miller et al., 1994). On smaller lakes with no stream, birds might be forced to walk to another suitable lake, generally a distance of at least $0.8 \mathrm{~km}$. This would be energetically expensive, and would subject birds to predators such as the arctic fox (Alopex lagopus) (Derksen et al., 1979).

If brant are unable to avoid disturbance, model results indicate that up to 4585 birds ( $25 \%$ of the molting population in the study area) could experience heavy weight loss as a result of intense Bell 412 activity along the coast. Minimizing disturbance to the birds by managing helicopter activity on the molting grounds is a viable option.
This model has identified slight changes in the most practical routes that could result in greatly reduced disturbance to the molting population. When flying across the Cape Halkett region, pilots could reduce the number of birds experiencing heavy weight loss up to $91 \%$ by following the Cape Route rather than the Direct Route. Following the Coastal-Seaward Route rather than the other two coastal routes also might greatly reduce disturbance. However, for safety reasons, pilots may not wish to fly $1.6 \mathrm{~km}$ offshore. Additionally, brant move to the coast immediately upon completion of molt (Jensen, 1990) and could be adversely affected by intense aircraft traffic along these flight lines. The Teshekpuk Route is shorter, and therefore less expensive, than the coastal routes. It avoids the Beaufort Sea and the coast, and of the six flight lines simulated, had by far the least impact on the molting brant population.

The model also identified alternatives that reduce disturbance along a given route either by changing helicopter type, varying flight altitude, or varying the pattern of overflights. Because the Bell 206 significantly reduces weight loss relative to the larger Bell 412, I suggest that the smaller helicopter be used when crew and payload size permit. Bell 206 overflights at altitudes $>1220$ $\mathrm{m}$ and Bell 412 overflights at altitudes $>1680 \mathrm{~m}$ virtually eliminate disturbance. Unfortunately, low cloud ceilings and poor visibility in this area often prohibit aircraft from flying at those altitudes. Although disturbance was generally inversely proportional to altitude, the greatest disturbance along all flight lines occurred at 305 or $460 \mathrm{~m}$, rather than at the lowest simulated altitude. This was probably because of shadow zones produced by wind that reduce the noise level of aircraft close to the ground (Ward and Stehn, 1989).

The model predicts that the effects of disturbance would be reduced greatly by restricting helicopter traffic to the first two weeks of molt. Because growth rate of the ninth primary wing feather for captive brant declines as molt progresses (Taylor, 1993), the model assumes that the amount of energy required for flight feather replacement declines greatly in late molt. Thus, birds undisturbed in late molt can rapidly regain body weight lost from helicopter activity during early molt. As mentioned above, heavy aircraft traffic immediately prior to molting might cause birds capable of flight to vacate an area. Thus, intense helicopter activity might best be confined to the second week of the fourweek molt period. This management action requires that molting be highly synchronized within the majority of the population. Derksen et al. (1979) found that the percentage of flightless brant on East Long Lake increased from approximately 1 to 89 in 2 days. However, Taylor (1993) found evidence of a later influx of brant into the study area on approximately 17 July 1988 and 1989. The number of birds that arrive on the molting grounds during this later influx is unknown, and should be determined before establishing a short window for intense helicopter activity.

This model is extremely useful in suggesting possible ways to reduce helicopter disturbance to molting brant by comparing alternative flight lines, altitudes and overflight patterns across the molting ground. Results predict that impact of helicopter activity can be reduced greatly by 1) following the Teshekpuk Route, 2) flying $>1065 \mathrm{~m}$ altitude, 3) flying only when most brant 
are in their second week of molt, 4) minimizing flight frequency, and 5) avoiding use of the Bell 412 when possible. Model users can easily enter and simulate any additional route or overflight pattern of interest. For example, flight frequency and altitude can be varied daily. Thus, this model should prove valuable in examining further possible compromises between preservation and development on the Arctic Coastal Plain that might allow for coexistence of helicopter activity and brant on the molting grounds. The model may also be applicable to other management scenarios involving spatial distribution of wildlife and human development.

\section{ACKNOWLEDGEMENTS}

This study was conducted through Cooperative Agreement\#14-160007-87-951 between Texas A\&M University and the Alaska Fish and Wildlife Research Center in Anchorage, Alaska. Funding sources include the United States Fish and Wildlife Service, the Bureau of Land Management, and the Mineral Management Services. The manuscript benefitted greatly from editorial reviews by Milton W. Weller, William Grant, Dirk Derksen, Karen McCullough and three anonymous reviewers. Dirk Derksen coordinated all aspects of the project and provided access to unpublished U.S. Fish and Wildlife Service aerial survey data of brant distribution and abundance. R.J. King conducted aerial surveys of molting brant. K.C. Jensen provided much advice, as well as unpublished data on helicopter disturbance of molting brant. David Ward answered numerous questions concerning a similar study on staging brant. K.C. Jensen, Stephen Adair, Keith McKnight and Eric Taylor wrote the bioenergetics model. K.C. Jensen, Jeff Odom, Karen Bollinger and Dr. Doug Slack collected helicopter overflight data. Steve Adair, Joe Moore, and Frances Mann gathered field data on forage and body condition of molting brant.

\section{REFERENCES}

ANKNEY, C.D. 1979. Does the wing molt cause nutritional stress in lesser snow geese? Auk 96:68-72.

1984. Nutrient reserve dynamics of breeding and molting brant. Auk 101:361-370.

BÉLANGER, L., and BÉDARD, J. 1989. Responses of staging greater snow geese to human disturbance. Journal of Wildlife Management 53:713-719.

BELLROSE, F. 1980. Ducks, geese, and swans of North America. Third edition. Harrisburg, Pennsylvania: Stackpole Books. 540 p.

BLACK, R.F., and BARKSDALE, W.L. 1949. Oriented lakes of northern Alaska. Journal of Geology 57:105-118.

BURGER, J. 1981. The effect of human activity on birds at a coastal bay. Biological Conservation 21:231-241.

CONROY, M.J. 1993. The use of models in natural resource management: Prediction, not prescription. Transactions of the North American Wildlife and Natural Resources Conference 58:509-519.

DAHLGREN, R.B., and KORSCHGEN, C.E. 1992. Human disturbances of waterfowl: An annotated bibliography. U.S. Fish and Wildlife Service Resource Publication 188. 62 p.
DERKSEN, D.V., ELDRIDGE, W.D., and WELLER, M.W. 1982. Habitat ecology of Pacific black brant and other geese moulting near Teshekpuk Lake, Alaska. Wildfowl 33:39-57.

DERKSEN, D.V., WELLER, M.W., and ELDRIDGE, W.D. 1979. Distributional ecology of geese molting near Teshekpuk Lake, National Petroleum Reserve-Alaska. In: Jarvis, R.L., and Bartonek, J.C., eds. Management and biology of Pacific Flyway geese. Corvallis, Oregon: Oregon State University Book Stores, Inc. 189-207.

EINARSEN, A.S. 1965. Black brant: Sea goose of the Pacific coast. Seattle: University of Washington Press. $142 \mathrm{p}$.

EISENHAUER, J.H. 1977. Nesting ecology and behavior of Pacific black brant in Alaska. M.S. Thesis. University of Lethbridge, Lethbridge, Alberta, Canada. 257 p.

FRETWELL, S.D. 1972. Populations in a seasonal environment. Princeton, New Jersey: Princeton University Press. 217 p.

HARAMIS, G.M., NICHOLS, J.D., POLLOCK, K.H., and HINES, J.E. 1986. The relationship between body mass and survival of wintering canvasbacks. Auk 103:506-514.

HULTÉN, E. 1968. Flora of Alaska and neighboring territories: A manual of the vascular plants. Stanford, California: Stanford University Press. $1008 \mathrm{p}$.

JENSEN, K.C. 1990. Responses of molting Pacific black brant to experimental aircraft disturbance in the Teshekpuk Lake Special Area, Alaska. Ph.D. Thesis. Texas A\&M University, College Station, Texas. $69 \mathrm{p}$.

JENSEN, K.C., and ADAIR, S.E. 1988. A simulation model of potential impacts of aircraft disturbance on energy flow in molting Pacific black brant in the Teshekpuk Lake Special Area, Alaska. Unpubl. ms. 13 p. Available from Steve Adair, Arcadia Plantation, P.O. Drawer 458, Georgetown, South Carolina 29442, U.S.A.

KING, J.G. 1970. The swans and geese of Alaska's arctic slope. Wildfowl 21:11-17.

KING, J.G., and HODGES, J.I. 1979. A preliminary analysis of goose banding on Alaska's arctic slope. In: Jarvis, R.L., and Bartonek, J.C., eds. Management and biology of Pacific Flyway geese. Corvallis, Oregon: Oregon State University Book Stores, Inc. 176-188.

KING, J.R. 1974. Seasonal allocation of time and energy resources in birds. In: Paynter, R.A. Jr., ed. Avian energetics. Cambridge, Massachusetts: Nuttall Ornithological Club No. 15. 4-85.

KRAMER, G.W., RAUEN, L.R., and HARRIS, S.W. 1979. Populations, hunting mortality, and habitat use of black brant at San Quintin Bay, Baja California, Mexico.In: Jarvis, R.L., and Bartonek, J.C., eds. Management and biology of Pacific Flyway geese. Corvallis, Oregon: Oregon State University Book Stores, Inc. 242-254.

LANCIA, R.A., NUDDS, T.D., and MORRISON, M.L. 1993. Opening comments: Slaying slippery shibboleths. Transactions of the North American Wildlife and Natural Resources Conference 58:505-508.

MADSEN, J. 1985. Impact of disturbance on field utilization of pinkfooted geese in West Jutland, Denmark. Biological Conservation 33:53-63.

MILLER, M.W. 1991. A simulation model of the response of molting Pacific black brant to helicopter disturbance. M.S. Thesis. Texas A\&M University, College Station, Texas. 86 p. 
MILLER, M.W., JENSEN, K.C., GRANT, W.E., and WELLER, M.W. 1994. A simulation model of helicopter disturbance of molting Pacific black brant. Ecological Modelling 73:293-309.

MOSBECH, A., and GLAHDER, C. 1991. Assessment of the impact of helicopter disturbance on moulting pink-footed geese Anser brachyrhynchus and barnacle geese Branta leucopsis in Jameson Land, Greenland. Ardea 79:233-238

OWENS, N.W. 1977. Responses of wintering brent geese to human disturbance. Wildfowl 28:5-14.

PAINE, R.B. 1972. Mechanisms and control of molt. In: Farner, D.S., and King, J.R., eds. Avian biology, vol. 2. New York: Academic Press. 104-155.

PEHRSSON, O. 1987. Effects of body condition on molting mallards. Condor 89:329-339.

PENFOLD, M.J., and BUOY, L.J. 1986. Combining agency goals to meet wildlife needs and manage oil and gas resources in Alaska. Transactions of the North American Wildlife and Natural Resources Conference 51:98-106.

PÉWÉ, T.L. 1975. Quaternary Geology of Alaska. U.S. Geological Survey Professional Paper 835. $145 \mathrm{p}$.

RICHMOND, B., PETERSON, S., and VESCUSO, P. 1987. An academic user's guide to STELLA. Lyme, New Hampshire: High Performance Systems, Inc. 392 p.
SMITH, R.H., and JENSEN, G.H. 1970. Black brant on the mainland coast of Mexico. Transactions of the North American Wildlife and Natural Resources Conference 35:227-241.

SPETZMAN, L.A. 1959. Vegetation of the arctic slope of Alaska. U.S. Department of the Interior Geological Survey Paper 302-B. 39 p.

TAYLOR, E.J. 1993. Molt and energetics of Pacific black brant (Branta bernicla nigricans) on the Arctic Coastal Plain, Alaska. Ph.D. Thesis. Texas A\&M University, College Station, Texas. 285 p.

WAHRHAFTIG, C. 1965. Physiographic divisions of Alaska. U.S. Geological Survey Professional Paper 482. 52 p.

WARD, D.H., and STEHN, R.A. 1989. Response of brant and other geese to aircraft disturbance at Izembek Lagoon, Alaska. U.S. Fish and Wildlife Service Final Report No. 14-12-0001-30332. 193 p.

WARD, D.H., STEHN, R.A., and DERKSEN, D.V. 1994. Response of staging brant to disturbance at the Izembek Lagoon, Alaska. Wildlife Society Bulletin 22:220-228.

WELLER, M.W., JENSEN, K.C., TAYLOR, E.J., MILLER, M.W., BOLLINGER, K.S., DERKSEN, D.V.,ESLER,D., and MARKON, C. In press. Assessment of shoreline vegetation in relation to use by molting black brant (Branta bernicla nigricans) on the Alaska Coastal Plain. Biological Conservation.

WIGGINS, I.L., and THOMAS, J.H. 1962. A flora of the Alaskan arctic slope. Arctic Institute of North America Special Publication No. 4. Toronto: University of Toronto Press. 425 p. 